\title{
Os lugares do fotográfico em fotofilmes espanhóis contemporâneos
}

/////////////////// Fernando de Tacca ${ }^{1}$

1. Professor livre-docente na Universidade Estadual de Campinas.

Contemplado com o Prêmio Marc Ferrez de Fotografia (Funarte, 1984/2010) e com a Bolsa Vitae de Artes 2002. Em 2006, recebeu o Prêmio Zeferino Vaz de Reconhecimento Acadêmico e ganhou o Prêmio Pierre Verger de Ensaio Fotográfico (Associação Brasileira de Antropologia). Durante 2011 esteve na Espanha, com bolsa de pesquisa no exterior da Fundação de Amparo à Pesquisa do Estado de São Paulo. Atualmente é pesquisador do Conselho Nacional de Desenvolvimento Científico e Tecnológico. Criador e editor da revista Studium desde 2000:www.studium.iar.unicamp.br. E-mail: tacca@unicamp.br 


\section{Resumo}

O artigo analisa três filmes recentes de produção e diretores espanhóis nos quais o fotográfico ganha relevância e movimento no que é considerado como uma nova categoria ou mesmo como cinema experimental: fotofilmes (fotocine ou photocine). Os filmes analisados são: Unas fotos en la ciudad de Sylvia (Luis Guerin, 2007, 67’); El pabellón Alemán (Juan Millares, 2009, 14’); e El Baobab de piedra (Marco Potyomkin, 2010, 86’).

\section{Palavras-chave}

Cinema espanhol, fotografia, fotofilme.

\section{Abstract}

The article analyzes three recent films produced in Spain which the photographic gains movement in the picture to consider today like a new category, as photocine. The films analyzed are: Unas fotos en la ciudad de Sylvia (Luis Guerin, 2007, 67’); El pabellón Alemán (Juan Millares, 2009, 14'); and El Baobab de piedra (Marco Potyomkin, 2010, 86’).

Keywords

Spanish cinema, photographic, photocine. 
2. Sugiro ver: TACCA, F. C. de. "Fotografia e cinema: intertextualidades". Revista Studium

27. Disponível em: http://www. studium.iar.unicamp.br/27/03.html.
Fotografia e cinema tiveram muitos lugares-comuns desde suas origens, com múltiplas influências estéticas, técnicas e conceituais. Se por um lado a fotografia surgiu inicialmente nas primeiras décadas do século XIX, seu desenvolvimento técnico aliado ao uso de exploração de sequências fotográficas irá possibilitar muitos anos depois, no final do mesmo século, a criação do cinema. Este por sua vez tornou o formato $35 \mathrm{~mm}$ um padrão fotográfico a partir dos protótipos clássicos da câmera Leica — iniciados em 1913 —, produzidos a partir de 1924, acentuando a popularização a fotografia, criando rapidez em ações inóspitas e persistindo até os dias de hoje, mesmo de forma nostálgica.

A fotografia alçou novo lugar no cinema com o referencial filme La Jetée, de Chirs Marker, em 1963. No filme, preencheuse a tela inteira com fotografias em sequências, acentuando significações e ressaltando temporalidades da imagem. Inúmeros também são os exemplos da presença da fotografia na narrativa cinematográfica preenchendo nós temporais ao criar elipses para situações futuras ou passadas. $^{2}$

Recentemente, através dos processos digitais de captação e processamento da imagem, a produção com animações de fotografias tornou-se popular, sendo encontrada desde a publicidade até produções caseiras. Ainda no tempo analógico, as dificuldades de filmar, revelar películas e usar dispositivos como o table top restringiam muito esse tipo de produção e montagem. Hoje em dia, popularizou-se a presença dessas produções no YouTube. 
Depois de um levantamento sobre a produção de filmes contemporânea espanhola nos quais o fotográfico é fator fundamental do narrativo, escolhi os que, a meu ver, são os mais importantes por múltiplos aspectos intrínsecos a cada realização, montagem e processo de significação e que pretendo analisar nos decorrer do presente artigo. São os seguintes filmes: Unas fotos en la ciudad de Sylvia (Luis Guerin, 2007, 67'); El pabellón Alemán" (Juan Millares, 2009, 14’); e El Baobab de piedra (Marco Potyomkin, 2010, 86’).

Cinco outros filmes encontrados não fazem parte da presente análise, mas é importante citá-los nesse tipo de produção espanhola recente e merecem destaques pela importância que o fotográfico assume na narrativa. São eles: El mueble de las fotos (Giovanni Maccelli, 2008); Como se no estuviera (Francesco Bartoli, 2010); Joropo (Javier Codesal, 2010); Caso Céspedes (Cabello \& Carceller, 2010); The other/Apuntes sobre el outro (Sergio Oksman, 2009).

\title{
Uma fantasia fotográfica, ou somente uma fantasia...
}

\begin{abstract}
Sólo la vio una vez en la vida. Y la visión duro apenas un segundo, quizá uma fracción. Pero no la há olvidado, y siempre se preguntará si no fue un error que no se decidiera a tiempo a cambiar de andén del metro y tratar, siquiera, de meterse en el vagón en el que ella viajaba, em dirección contrária... (La visión, Miguel Marías).
\end{abstract}

Escolher a epígrafe acima para começar minhas observações sobre o fotofilme Unas fotos en la ciudad de Sylvia (Luis Guerin, 2007) liga-o diretamente com o conto La Visión, de Miguel Marías. Nada novo nesse itinerário, pois o texto aparece citado por poucos instantes na narrativa do filme como "um conto enviado por um amigo" e foi posteriormente publicado pela primeira vez no encarte do DVD no qual a película foi comercializada. A relação e a amizade entre os dois são muito anteriores a esse momento. Guerin, motivado pela leitura de uma crítica de um jovem de então somente 14 anos, Miguel Marías, o chamou sete anos depois para 
apresentar seu primeiro filme de longa-metragem, Los Motivos de Berta, em 1983. Ambos tinham então 23 anos. Portanto, mais que uma amizade, transparece uma relação de admiração entre ambos, uma relação intrinsecamente afetiva e intelectual.

O filme Unas fotos em la ciudad de Sylvia inicialmente era somente uma aventura fotográfica obsessiva de busca de uma mulher que o diretor teria conhecido em um café na cidade francesa de Estrasburgo e da qual diz ter poucas, ou quase nenhuma lembrança: somente seu nome, Sylvie. Nem ao menos se recorda de seu rosto; tem somente uma vaga lembrança de uma mulher que o marcou em determinado momento de sua vida. Um encontro fugaz e de passagem. Guerin nos diz isso logo no começo, pois o filme tem característica de um diário relatado em primeira pessoa. Na verdade, quando digo que Guerin nos diz, é uma metáfora, pois o filme é mudo, com intertítulos entre ensaios fotográficos e algumas legendas diretamente sobre as fotografias, o que podemos chamar de um fotofilme, com características documentais ancoradas nas fotografias pessoais do diretor. Unas fotos..., como é tratado em muitos textos, foi um pré-roteiro, um esboço, ou lugar de gestação de outro filme de Guerin, com características ficcionais: En la ciudad de Sylvia (Guerin, 2007).

Por quatro anos, Guerin percorreu muitas cidades europeias obcecado pela procura de uma mulher enigmática, construindo uma fantasia fotográfica como um lugar detetivesco da procura do amor não encontrado e, ao mesmo tempo, perdido. Transparece uma relação de um amor romântico, ou a busca do amor impossível, platônico, do não concretizável, do quase proibido, pela própria ausência de lembranças mais fortes e densas. Assim, vários desses amores serão citados no decorrer da narrativa, como de Goethe por Charlotte (ou Lotte), na própria cidade de Estrasburgo. A única vez que Guerin esteve com Sylvia teria sido nessa cidade meio francesa e meio alemã, na Alsácia, quando o diretor ali esteve na juventude, e a encontrou em um café. Informa que tem somente três recordações de Sylvia: estudou alguns meses na cidade de Salamanca; gostava do som de seu nome em espanhol (seu nome original era Sylvie); e estava começando a trabalhar como enfermeira em um hospital. 
Guerin escreve: “Es todo”... “...ou casi”. Do encontro, guardou como recordação poucas coisas, entre elas, um suvenir: uma caixa de fósforos do bar Les aviateurs. Talvez, algumas poucas centelhas para procurar Sylvie, transformada em Sylvia.

Identifica-se com o romantismo de Goethe, sua subjetividade, melancolia, individualismo, imaginação e, é claro, idealização da mulher e do amor. Não para por aí, e vai à busca de outros amores impossíveis da literatura, como o de Dante por Beatrice, na cidade de Florença, imortalizada em suas obras. $\mathrm{O}$ autor italiano diz que somente a viu duas vezes na vida. E ainda do amor de Petrarca por Laura, imaginária ou real, na cidade de Avignon. Todas essas referências de amores impossíveis se apresentam como lugar escolhido pelo fotógrafo/diretor, como uma espécie de esconderijo para um efetivo encontro, e a câmera opera ainda mais como intermediação com o real: funciona como biombo. A busca por Sylvia é uma obsessão fotográfica traduzida em inúmeros retratos, muitos deles de forma oculta, escondido na multidão, como o fotógrafo de Blow up, em meio aos arbustos das árvores. Mas, ao contrário do épico filme de Antonioni, o contato direto, sem intermediação "maquínica”, não se realiza. Parece-nos que o fotógrafo escolhe se esconder de alguma possibilidade efetiva do encontro, sendo a gestualidade do ato fotográfico um lugar de recolhimento, ilusão e introspecção. O encontro, ficcionalizado pelo diretor ao final do filme, em verdade não ocorreu em sua vida pessoal.

Guerin, como um estereótipo de fotógrafo, viaja e, de passagem por essas cidades, e outras, como Barcelona, Lisboa e Madri, lança-se na aventura da perseguição de rostos e de mulheres, criando uma relação obsessiva com o ato fotográfico. Muitas situações sobre essa possível relação patológica são tratadas em obras literárias e no próprio cinema. Nesse sentido, o próprio ato é mecânica gestual mais de afastamento do que de encontro, ou seja, é lugar de distanciamento e alimentação de um substrato psíquico da frágil memória afetiva com a mulher essencial, ou com todas as mulheres. Guerin descobre Sylvia em todas as possíveis mulheres que observa, e ao mesmo tempo a dissolve na multidão de rostos fotografados pela falta de um sentimento mais profundo com essa primeira mulher. 
Nuria Esquerra assina o filme como montadora e produtora e diz que, no final do ano de 2003, Guerin a procurou para montar algumas sequências com imagens que vinha recolhendo alguns anos antes; é um filme de uma "equipe" de duas pessoas, característica dos tempos atuais e das possibilidades de baixo custo, utilizando o meio digital. Relata que foram se formando ensaios com temas que o conjunto fotográfico permitia: tomadas de esperas, de lugares, de movimentos de bicicleta, bondes e metrô, de perseguições. Portanto, nunca houve um roteiro definido, e sim uma série de fragmentos pelos quais Guerin gestava uma ideia para outro filme, um esboço de roteiro para uma película com atores, produção, enfim, uma realização dentro dos parâmetros do cinema tradicional. O filme em gestão, En ciudad de Sylvia, foi finalizado no mesmo ano que Unas fotos..., em 2007, e participou de vários festivais de cinema. São díspares, complementares e dissonantes. Enquanto Unas fotos... tem uma narrativa em primeira pessoa, sem imagem em movimento, somente com fotografias em branco e preto, e sem som, En la ciudad de Sylvia, tudo se inverte. O que se mantém de fato entre um filme e outro é a busca por um rosto anônimo, marcado por enquadramentos muito similares presentes inicialmente em Unas fotos... No filme ficcional, mantêm-se muitas cenas de perseguição pelas ruas pela mulher imaginária, uma busca também obsessiva, e, obviamente, a principal mulher perseguida não era Sylvia nem Sylvie. O fotógrafo da primeira película se transmuta em um pintor, que observa as pessoas e a cidade e flana sobre elas, e da relação maquínica inicial com a realidade, relatada em primeira pessoa, nasce outra, realizada pela observação e desenhos instantâneos que o personagem faz das pessoas.

Guerin mostrou o que seria inicialmente o "filme" para um grupo seleto de amigos e, nesse sentido, Esquerra afirma:

Esta escritura solitária, semejante a la de un diario intimo, un ensayo, o como dice Guerin, una fantasia fotográfica, quizá nadie más la hubiera visto a no ser de estos primeros espectadores - entre los que me incluyo - , que le animamos para que la compartiera con el público (ESQUERRA, 2008, p. 44). 
Em Unas fotos..., Guerin mostra-se como um excelente fotógrafo - um fotógrafo de pessoas e de ruas - , que se extasia e entra em transe fotográfico, mergulhado no processo "maquínico" de produção de imagens. A cidade é cenário para os retratos, e, ao contrário de Atget, Guerin é um "flaneaur" de pessoas, com as cidades existindo de fundo. Parece-nos o mítico fotógrafo de muitas histórias literárias e cinematográficas, sempre de passagem, sem tempo para relações pessoais - somente sua imersão solitária em pensamentos e imagens. As cenas nos muitos hotéis pelos quais passa nessa busca solitária somente são interrompidas pelo anúncio do recebimento do conto de Miguel Marías. E uma passagem do conto o faz voltar para Madri, cidade distante da mítica Sylvia, e que também se presentifica em um longo ensaio fotográfico sobre um rosto anônimo na estação de metrô de Alonso Martínez:

Habia conocido a muchas otras mujeres atractivas, en mejores y más propicias circunstancias, y - curiosamente - a todas las había comparado con la imagen retenida de la desconocida del metro de Alonso Martínez; no pocas le parecieron muchas más atractivas, aunque no lograron disipar su imagen indelével (MARÍAS, 2008, p. 56).

3. Sobre a construção do personagem "fotógrafo" na literatura, sugiro ver o artigo: "O fotográfico na literatura”. Revista

Facom (Faap), n. 23, p. 40-63, 2011. Disponível em:

http://www.faap.br/revista_faap/ revista_facom/facom_23/index.html.
Nessa passagem do filme, inspirada no conto de Miguel Marías, Guerin também se centra em um rosto em espera, que o permite fotografar obsessivamente. Mas ele está do outro lado, em plataforma oposta, o que não lhe permite aproximação física, somente ótica. E essa aproximação ótica é um biombo para possível relação e nos lembra da obsessão do personagem Antonino Paraggi, no conto A aventura de um fotógrafo, de Ítalo Calvino ${ }^{3}$, que transforma sua relação com a sua amada em uma situação intermediada pela mecânica e pela ótica do aparelho.

Marías insiste em colocar o filme de Guerin como inovador e algo novo dentro da linguagem cinematográfica. Compartilho com Marías que o formato longo, silencioso, montado através de ensaios e intertítulos com características pessoais de um diário e com uma equipe de somente duas pessoas - o fotógrafo diretor e a montadora/produtora - , surpreende um espectador não 
acostumado a tal categoria de cinema, que podemos chamar de fotofilme; entretanto, podemos localizar esse tipo de produção desde os anos 60. Claro está que a ausência de uma trilha sonora fortalece os vínculos entre as imagens, não amenizando nem fortalecendo possíveis relações significativas, o que torna a película sui generis para sua duração de mais de uma hora, exatamente 67 minutos. Não é efetivamente uma película comercial, nem com perspectiva de apresentação em salas normais de cinema.

Cabe destacar que por duas vezes o filme foi apresentado com um pequeno grupo de música de câmara, com composição de Paula Yturriaga, criada para esse fim. Primeiro, no Festival de Cine de Gijón de 2007 e, posteriormente, no Festival Punto de Vista - Festival Internacional de Cine Documental de Navarra, 2008. A escolha de apresentação acompanhada por músicos coloca, sem dúvidas, novas questões sobre a montagem inicial sem som; afinal, é assim que foi comercializada em DVD. Se referenciarmos aqui um filme que explora intensamente o quadro a quadro, como um instante fotográfico, no caso de Koyaanisqatsi (Godfrey Reggio, 1982), com música de Philip Glass, também encontramos várias apresentações com performances do músico ao vivo acompanhando a película.

No caso silencioso de Unas fotos..., podemos nos aproximar do diário do fotógrafo diretor, principalmente pelos silêncios visuais entre ensaios fotográficos e entre fotografias, nos quais trilha ou música incidental poderia fazer crescerem outros significados, mas não deixa de ser uma experiência difícil e angustiante para o espectador. Esquerra justifica a ausência da trilha sonora e encontra valores implícitos nela:

El montaje de sonido contribuye, entre otras cosas, a dotar de ritmo interno a las imágenes, a ligarlas entre ellas, a sumar otras lecturas a la imagen, al contrapunto, a crear resonancias... La ausencia de banda sonora, pues, provoca que el espectador cambie el tiempo de lectura de las imágenes al que está acostumbrado, y que adopte una concentración interpretativa de distinta clase, quizá más cercana a la que tendría un lector (ESQUERRA, 2008, p. 43). 
4. CCCB - Centro de Cultura Contemporânea de Barcelona, 2008.
A opção pelo silêncio marcado pelos intertítulos faz que as imagens, com suas fusões e pequenas narrativas, ganhem dimensão temporal muito distinta de imagens em movimento, ou mesmo de fotografias animadas com narrativa em off, como o caso do clássico La jetée (Chris Marker, 1962). A película ganha novo corpo com música ao vivo, estendendo suas possibilidades expressivas, assim como também outras apresentações, como uma instalação convidada para integrar o Pavilhão Espanhol da Bienal de Veneza em 2007 e na mostra Las mujeres que no conocemos. ${ }^{4}$ A instalação foi realizada a partir dos fragmentos editados para o filme Unas fotos..., apresentados em telas simultâneas, quebrando a linearidade do filme, ou seja, novos desdobramentos da narrativa inicial. Restam ainda, talvez, para completar visualidades do trabalho, uma exposição fotográfica de imagens escolhidas ou ensaios fotográficos selecionados, como exposições fotográficas de Chris Marker afinal, a matéria-prima são imagens fixas.

A busca pelo amor impossível ainda permeia muitas almas e corações nos tempos atuais, de relações fragilizadas pelas relações amorosas transitórias. Em Verona, a casa mítica de um romance literário, Romeu e Julieta, de William Shakespeare, tornou-se um evento turístico, com presença de multidão de pessoas de várias partes do mundo, um lugar para alimentar essa ilusão. A casa de Julieta nada mais é que a casa escolhida pelo diretor Franco Zeffirelli, na clássica versão de 1968, ou seja, uma casa cenográfica, mesmo que real, elevada a manifestações de amor eterno e, por que não, impossível.

O encontro do jovem Guerin com Sylvie, na cidade de Estrasburgo em 1984, tornou-se a busca por outra mulher: Sylvia, na mesma cidade e em muitas outras. Do encontro físico com Sylvie nada restou - poucas memórias sem muita importância - ; se de fato ocorreu o encontro ou foi uma ficção do autor, não importa; somente que não restaram lembranças da conversa nem de seu rosto, somente palitos de fósforos, centelhas de chamas não friccionadas. Guerin encontrou-se com Sylvie, procurou Sylvia, não conheceu ambas. Ao final, em 13 intertítulos, ele traduz sua procura: 


\begin{abstract}
Una mujer conduce a outra mujer que conduce a otra... todo bajo la advocación de una imagen secreta: ella no apareceria... pero estarían en terrazas, fachadas, puentes, canales, mercados, hospitales, tranvías, y extraradios... y los grafitos que proclaman el amor por una mujer y los anuncios de la desaparecida... y otros rostos capaces de evocarla... yestarían también los comerciantes, repartidores, camareros, heladeras, pensionistas, estudiantes, niños, amantes, turistas, chochards... La ciudad y el rostro... la localización y el personaje... el entorno y la figura... la figura ficción... el entorno documental... Um título provisional: "En la ciudad de Sylvia".
\end{abstract}

Para Guerin, restaram inúmeros rostos, ruas e cidades e a solidão do fotógrafo, alimentada pelo esforço do diretor de cinema; conheceu fugazmente uma mulher chamada Sylvie; procurou fotográfica e obsessivamente, e não encontrou outra mulher, chamada Sylvia. Talvez tenha encontrado um filme. Ou melhor, dois.

\title{
Amanhecer: em que pesem as luzes da história
}

A obra e o pensamento de Jóan Fontcuberta são muito instigantes para pensarmos questões pertinentes de novas fronteiras do fotográfico, entendido como um lugar do ficcional, ou seja, um meio expressivo também como lugar da invenção. Fontcuberta nos oferece um itinerário histórico desde o engraxate de Daguerre e seu cliente postados no boulevard du Temple, em Paris. Sobre as duas tomadas que Daguerre realizou de sua janela, Fontcuberta alerta sobre as possibilidades além de uma imagem mera e somente documental. Diz o autor:

Esse episódio acrescenta, em suma, uma valiosa aproximação para uma filosofia da fotografia: o uso estritamente documental da câmara fracassa em seu intento de captar a realidade viva; é somente enganando que podemos alcançar certa verdade. É somente com uma simulação consciente que podemos nos acercar de uma representação epistemologicamente satisfatória (FONTCUBERTA, 2010, p.107). 
Fontcuberta complementa analisando em outro texto uma série de eventos visuais, históricos ou artísticos, nos quais o fotográfico falha na sua premissa indicial e documental, e o autor toma como princípio o jogo de palavras de Jean-Luc Godard: substituir photographie por faux-tographie. O conceito de contravisión foi utilizado pela primeira vez por Fontcuberta em ensaio publicado na revista The Village Cry (1977), e o autor o retoma em texto recente, atualizando-o:

Propunha que a contravisão deveria ser entendida como uma ação de ruptura com as "rotinas" (segundo sua concepção em informática) que controlam os "programas" do pensamento visual: atuar com um hacker atacando as defesas vulneráveis do sistema. A contravisão deveria corromper o princípio de realidade designado à fotografia e não representava tanto uma crítica da visão, mas da intenção visual (FONTCUBERTA, 2009, p. 184).

O filme El pabellón Alemán (Juan Millares, 2009) comparte o pensamento crítico de Fontcuberta e se coloca entre o documental possível e a ficção, deslocando-nos para um lugar da contravisão das imagens existentes e do próprio momento histórico. Juan Millares, arquiteto formado nos anos 60, esteve envolvido com a paradigmática construção modernista de Mies van der Roche, na qual se deparou somente com velhas fotos em branco e preto, que segundo ele tinham uma existência fantasmagórica: “...vacías como todas las fotos que ilustran libros de arte y arquitectura. Aquellas fotos eran los únicos testimonios documentales de que aquel asombroso objeto había existido realmente" (MILLARES, 2011). Envolvido no mistério da ausência do edifício, e somente imerso na sua existência imagética, Millares se deparou em 1986 com a reconstrução do prédio, e seu projeto de um filme quase desaparece: "De pronto todo el entramado imaginativo implícito en las viejas imágenes se esfumó sin más. El pabellón de Mies volvia a ser real, físico, pesante, em toda sua plenitud material y cromática" (MILLARES, 2011).

Millares nos relata que sempre teve muitas dificuldades em trabalhar imagens domésticas ou de álbuns familiares, pelas 
questões subjetivas que permeiam nosso olhar sobre esse tipo de fotografia. Entretanto, apesar da relutância, e depois de dificuldades em elaborar algo a partir delas, afirma que encontrou uma chave: era a própria imagem. "La clave estaba el na própria imagen. En lo que la imagen, de manera incluso sorpreendente para los conocedores de sus circunstancias, podía revelarnos. La forma fotográfica debería darnos pues la pauta para interpretarla" (MILLARES, 2011). Dessa forma, depois de afastamento das velhas imagens do pavilhão de Mies, e após reflexão sobre como se aproximar da fotografia familiar, principalmente pela descoberta do conceito barthesiano de punctum, voltou ao seu projeto de realização de um filme: “... venía a dar una mayor complejidad a mi interes por los enigmas implícitos en la fotografía y la revelación de sus significados ocultos" (MILLARES, 2011).

O princípio estrutural e conceitual de sua película centra-se na proposição de uma narrativa fílmica na qual o fotograma é o agente principal, como ponto de partida e de chegada do relato fílmico (“...su invisible unidad genética”). Diferenciado, portanto, da temporalidade e ritmo do cinema tradicional de imagem em movimento, e com influências dos filmes La jetée (Chris Marker, 1962) e O rosto de Karin (Ingmar Bergman, 1984), sente-se então à vontade para contar histórias, construir narrativas sobre as velhas imagens do pavilhão.

Uma rua estreita de Paris, um hotel barato, algumas carroças, um lugar vazio: reconhecemos a foto de Atget. Um piano cândido acompanha nosso olhar sobre a foto, que fica à nossa espera, inteira na tela. Outras fotos de Atget são apresentadas; são fotos de uma cidade que não existe mais. As imagens continuam a mostrar lugares vazios, em grande silêncio. Um deleite para os fotógrafos, pois reconhecemos Eugène Atget desde logo, assim como suas "andarilhagens" fotográficas pela cidade de Paris na virada do século XIX. Atget fotografava nas primeiras horas da manhã: assim, as ruas ainda não estavam tomadas, e, quando alguém se colocava no enquadramento, a baixa velocidade do diafragma tornava-a um espectro, uma existência fantasmagórica. Como lugar de um conceito, surge Walter Benjamin, anunciado em cartela, como nos 
filmes mudos, e esse pensador penetra nas possibilidades de um não anunciado acontecimento, o lugar de um crime não resolvido, que se mostra somente pelos indícios, e pelos seus detalhes.

O piano muitas vezes enaltece nosso olhar, chama a atenção quando acompanhamos planos em movimento da câmera sobre a imagem. Possíveis crimes burgueses ou proletários que deixam marcas no vazio fotográfico, ou testemunhas fantasmagóricas de um tempo longo de exposição se convertem em dúvidas de um possível depoimento. O clima e o silêncio das fotos de Atget são janelas para o texto, para o imaginativo, ou seja, para a ficção.

Ancorado em pano de fundo conhecido da história da fotografia, Juan Millares anuncia seu foco em uma possível ficção de um possível crime, baseando-se conceitualmente nas observações de Walter Benjamin sobre os vazios e espectros humanos das fotos de Eugene Atget. A possível trama é vista através das fotografias que restaram do conhecido pavilhão Alemão, do arquiteto Mies van der Rohe, construído para a Exposição Universal de Barcelona, em 1929. Os personagens retratados foram demoradamente pesquisados, quem eram e o que estavam fazendo ali, seus lugares de poder, assim como os vazios fotográficos. O filme foi realizado a partir somente de imagens originais que restaram, pois o pavilhão foi desmontado no ano seguinte. Entre elas, surge a magnitude da escultura expressionista Amanhecer, de Georg Kolbe: uma mulher que parece tentar se esconder ou se proteger de algo, talvez dos primeiros raios de sol ou então como única testemunha de um crime. Diz ele:

Toda aquella colección de personagens desapareció en las densas brumas del pasado histórico. Aparte del elegante espacio miesiano, el único elemento figurativo testigo de los hechos imaginados que me empeñaba en contar era la estatua de Kolbe, titulada Amanecer. Su gesto de rechazo a una supuesta luz de la mañana terminaba de completar la avalancha de significados que las fotos del pabellón había desencadenado (MILLARES, 2011).

Memória, fotografia e cinema se envolvem em um clima de beleza plástica e de poética audiovisual, no qual ficção e realidade dialogam 
sem fronteiras. Millares opta por uma estratégia de montagem na qual muitas histórias podem estar escondidas nessas mesmas imagens e, ao final, nos alerta sobre tragédias humanas delineadas nos encontros do poder. São imagens que restaram, pois o pavilhão foi desmontado no ano seguinte. Muitos se debruçaram para admirar a ousadia dos espaços vazios propostos por Mies van der Rohe. Em meio às imagens de formas, linhas e curvas, espelhos, e transparências, emerge com magnitude a escultura expressionista Amanhecer, de Georg Kolbe, cujo original está até hoje em uma praça na Alemanha. A mulher parece tentar se esconder ou se proteger de algo, como única testemunha de um crime. A cópia de Amanhecer é fotografada hoje em dia por todos seus possíveis ângulos pelos visitantes do pavilhão, e se procurarmos na Internet iremos encontrar um grande conjunto de imagens da cópia e poucas do original.

Assim, a escultura é o marcador para que Millares nos faça deleitar em seguida com um clima detetivesco sobre as poucas fotografias que restaram envolvendo as principais autoridades presentes, principalmente pelo fato de o rei Alfonso XIII ser conhecido como o rei pornográfico, e teria se encantado com a belíssima baronesa alemã que acompanhava seu marido, barão Georg von Schnitzler, o comissário enviado para representar o governo alemão. Outros personagens, a rainha Eugenia, o ditador Primo de Rivera, o bispo, o próprio arquiteto autor do pavilhão, camareiros, possíveis espiões, anônimos, são "escaneados" em detalhes para percebermos seus olhares e gestos significativos de um acontecimento oculto, como pressentimento de um fato trágico. A baronesa em um costume branco, pequeno chapéu, com sua graça, se destacava das sombrias mulheres espanholas: todas de negro. O rei, obcecado pela alemã. Entretanto Millares nos desaponta: indica que talvez nunca tenha ocorrido um mistério, ou um crime não desvendado na inauguração do pavilhão. Ficamos inicialmente frustrados, para em seguida nos surpreendermos com o final. Um personagem torna-se o nó de crimes de lesa humanidade, que virão a seguir nos acontecimentos históricos, nas aproximações 
entre fascistas e nazistas, como os bombardeios alemães da Legião Condor na Guerra Civil Espanhola ou a morte por gás nos campos de concentração durante a Segunda Grande Guerra, e a inicial ficção torna-se uma trágica realidade.

O pavilhão foi reconstruído em 1986, e Millares o chama de um "luxuoso parque temático para turistas da cultura". O que vemos é o sempre gesto mecânico de registrar dos turistas em passagem rápida pelos lugares, sem perceber que ali, no original prédio, um conluio se montava para desmontar a Segunda República na Espanha e a República de Weimar, na Alemanha. Muitos crimes são revelados então. El pabellón Alemán venceu o Concurso Iberoamericano de Documentário Curta-Metragem, da $38^{\text {a }}$ edição do Festival Internacional de Huesca, em junho de 2010, e foi indicado ao Prêmio Goya, em 2011.

A música que nos conduz é primordialmente escolhida e editada. Entre elas, Erik Satie sobressai. A relação da música com as imagens, o trânsito e navegabilidade da câmera por elas, junto com a envolvente narrativa, possibilitam muitas camadas de significação e leitura. Memória, fotografia e cinema se envolvem em um clima de beleza plástica e de poética audiovisual. É somente no final que nos damos conta de que não havia voz em off. Somente palavras, som e imagens em cartelas ou em legendas nas imagens. Saímos com uma possível voz em off em nossos ouvidos, a nos alertar sobre as tragédias delineadas para a humanidade em encontros do poder.

El pabellón Alemán é referência para pensarmos as fotografias chamadas documentais como plenas de outras histórias obscurecidas que já lhe são consagradas pelo seu próprio roteiro histórico, artístico ou cultural. Millares nos propõe ficcionar o documental para que outras verdades sejam presentificadas dentro de uma ordem fenomenológica na experiência imaginativa. Millares lanças novas luzes sobre um evento histórico a partir de uma inicial ficcionalização do real que resulta em "consecuencias imprevisibles", ou como ele mesmo diz: 
5. O filme pode ser visto na íntegra no seguinte endereço: http://www. studium.iar.unicamp.br/32/l.html.

6. Para quem se interessar pela mítica árvore Baobab, sugiro ver o trabalho fotográfico de Elaine Ling, disponível em http://www.zonezero. com/zz/index.php?option=com_cont ent\&view=article\&id $=1245 \&$ catid $=2$ \&Itemid=7\&lang=es.
Como en el Aleph de Borges el pequeño pabellón de Mies podia contener todos los lugares de todos los crímenes de la modernidad. Lo que había empezado como un juego inocente con la imaginación y la imágenes se había convertido, sin que yo previera, en un relato más del horror contemporâneo (MILLARES, 2011).5

\section{Árvore da sabedoria: resistência e imaginário}

Uma árvore contém simbologia bastante para mobilizar socialmente um grupo de pessoas, mesmo existindo metaforicamente no imaginário de pessoas distante de seu habitat. A árvore em questão é o Baobab, mito de longevidade pelas dificuldades de sobreviver em lugares inóspitos e de transmitir espiritualidade à sua volta. Assim, muitos grupos étnicos da África veneram o Baobab como espírito de paz e de vida, pois pode conter muitos litros de água no seu caule. De existência magnífica, reinam sobre a vegetação rasteira das savanas africanas, podendo ser avistadas de muito longe na geografia descampada desses lugares, e se perpetuaram como signos de imponência, longevidade, sobrevivência e dignidade ${ }^{6}$. O título da película de Marco Potyomkin, El Baobab de piedra, finalizada em 2010, procura demonstrar que tal simbologia permeia o imaginário de imigrantes africanos que buscam novas vidas na Espanha. O principal motivador da narrativa foi a experiência de uma ação coletiva que propiciou uma casa-abrigo para moradores de rua, imigrantes africanos, vivendo em péssimas condições na cidade de Valência; experiência essa que infelizmente durou somente seis meses por questões políticas locais, ressaltadas na forte corrente conservadora na sociedade espanhola, com características xenófobas, que se fortalecem em momentos de crise econômica.

O filme, quase na totalidade realizado com fotografias, tendo inserções de desenhos e pinturas, pode ser considerado um fotofilme tradicional. Com 86 minutos de duração, torna-se integrante de um reduzido número de trabalhos de tal envergadura, que sustentam essa característica de fazer da imagem fixa um lugar de reflexão e de quando a imagem preenche todo o campo da tela e se mantém por muitos segundos aos nossos olhos. Com inspiração citada no início também em Chris Marker (“...por mostrar el camino”), enreda 
as fotografias quase como um slideshow, utilizando muito pouco as ferramentas de edição nas passagens entre as imagens, como também não navega a própria imagem, que sempre ocupa toda a tela como uma totalidade. O recurso de fade in e fade out é utilizado geralmente somente para marcar o fim de um determinado bloco como uma temporalidade fragmentária.

Uma longa introdução com fotos de muitos lugares do mundo, na voz do diretor, aborda a questão das migrações mundiais e da falta de alimentos e de condições de vida de povos e países submetidos a processos exploratórios. Essa introdução ressalta um "comunismo primitivo" e um conceito de "bom selvagem", não com tais palavras, mas um tempo no qual haveria fartura, liberdade e poucas doenças. O texto não relativiza os processos históricos de escravidão entre os povos ágrafos e das civilizações pré-capitalistas, como se a questão atual fosse a origem desses processos de submissão e de exploração. Dessa fala ressaltamos: “...el hombre y la mujer eran libres...", não questionando as diferenças e as submissões entre gênero, mas localizando-as como naturais, sem ao menos indicá-las, se esquecendo das mulheres mutiladas etnicamente na África. Surpreendentemente, a ideia de propriedade surge no contexto de mitologias africanas apresentadas em uma série de imagens que indicam essa questão dentro de rituais de mitos de origem que são compartilhados por alguns povos africanos. $\mathrm{Na}$ fala em off, a partir desse momento, tudo se transforma, e a humanidade torna-se implicitamente perversa, com cercas e alambrados. E o texto credita as enfermidades e as guerras à ideia de propriedade, com um discurso superficial, dogmático e ingênuo, recheado de belas imagens da natureza e de rituais e cerimônias de etnias distintas de várias partes do mundo. E assim, da fartura original e da "igualdade", as imagens coloridas da natureza passam para branco e preto, como processo de transição entre a vida e a morte. O tema das migrações então surge também sem as cores iniciais espetaculares da natureza e da cultura ativa, e as imagens de pessoas africanas são apresentadas sem cores, como se ao branco e preto fosse dado o lugar estético contemporâneo da tragédia e a da injustiça. O desconfortável e talvez insolúvel tema das migrações 
nos tempos atuais é assim introduzido, remetendo a uma saída para o livre trânsito, sem restrições, que um dia houvera na época idealizada da origem humana.

Toda a ação relacionada com a experiência social da casaabrigo é contada por um casal, um homem de origem africana vindo do Benin e uma mulher espanhola. O filme os apresenta em situação similar de experiência de vida fora de seus países de origem. No caso de Kuame Mensah, músico e original de Benin, ele fala de sua primeira saída de seu país para a França e das imposições que sua família teve de aceitar para conseguir o visto, mas não explica sua situação na Espanha. Tem uma visão crítica de todo o processo histórico pelo qual passou o continente africano desde a colonização ao período pós-colonização, e demonstra consciência também sobre a situação de seus conterrâneos na cidade de Valência. A entrada na sua fala é marcada inicialmente por sua própria música, acompanhada por um instrumento nativo, que nos apresenta criticamente os elementos do sofrimento da escravidão. Fotos do músico são intercaladas com desenhos e gravuras relatando as condições da escravidão, e em seguida apresenta-se o Baobab em uma série dinâmica de fotografias, com mais velocidade de montagem.

Inserções de relatos radiofônicos sobre a questão dos migrantes são acompanhadas de fotos noturnas, nas quais identificamos pessoas de origem africana andando pela noite ou pela madrugada, enquanto as falas nos remetem para a situação econômica atual e até mesmo para uma fala do provável presidente de governo, Mariano Rayol, do partido conservador PP, que afirma que tais pessoas deverão firmar contrato com o governo espanhol para aprender a língua e os costumes espanhóis, senão serão deportadas. Das fotos noturnas passa-se para fotos diurnas nos campos agrícolas e da submissão dos migrantes às condições de trabalho que lhes oferecem - e que eles têm de aceitar sem restrições. Abre-se então para as fotos diurnas, com narração do diretor, com texto poético e contundente sobre a exploração do trabalho do migrante, e temos claramente uma passagem que indica os caminhos dessas pessoas, ainda na madrugada, para chegar aos locais onde poderão ser 
contratados para um dia de jornada no campo. Nesse caso, também as imagens acompanham o suporte em áudio, acrescentando e fortalecendo a informação para o espectador, sem alinhar diretamente e sem descrever as imagens, somente indicando subjetivamente os caminhos de significação entre texto e imagens.

Patrícia Zaragozí, espanhola, que viveu em Nova Iorque, relata sua experiência de ser uma estrangeira (“...me considera como un inmigrante... un inmigrante de mierda..."), quando se aproximou da questão da imigração africana, e da própria musicalidade desses povos. De volta para Espanha, encontra-se com Kuame Mensah, e o casal consegue mobilizar, através da música, parte de uma sociedade consciente da questão e monta a casa-abrigo "El Baobab”, onde eles fazem a integração com os vizinhos e também com a cidade, na tentativa de resgatar dignidades fragilizadas dessas pessoas no seu deslocamento forçado da África para Valência.

Conforme as falas relatam o processo de transferência para a casa-abrigo, as dificuldades de mantê-la, e o fim da experiência, as imagens aproximam o espectador de todo o conjunto das questões, e principalmente das pessoas que participam da ação, sejam como motivadores da consciência, seja como o grupo social marginalizado.

O filme é dividido em várias partes e é polifônico, ou seja, é apresentado por muitas vozes: narração do próprio diretor, Marco Potyomkin; depoimentos em primeira pessoa de vários entrevistados; voz em off de textos poéticos; extratos de rádio e uma transmissão de um programa de rádio. No entremeio dessas muitas falas, relata-se, com muita dramatização, uma passagem já muito veiculada pela imprensa, quando da primeira entrada do presidente boliviano, Evo Morales, ainda sem as honrarias do posto e como cidadão comum, sendo obrigado a passar por uma situação constrangedora, pois tinha muito pouco dinheiro, e um policial lhe perguntou como pretendia viver com somente essa quantia, e ele respondeu que eles, os espanhóis, haviam levado tudo, restando somente essa quantia. Tal passagem em narração over é acompanhada de desenhos que mostram a submissão dos povos indígenas ao colonizador europeu e presentifica a exploração colonizadora com o momento atual. 
Da situação específica ocorrida na cidade de Valência, aparentando inicialmente o corpo central do documentário, a questão da migração se estende e irá abarcar outras questões que implicam Espanha e a imigração, principalmente a fronteira de Marrocos, com o enclave colonial ainda persistente da cidade de Melilla. Essa cidade espanhola dentro do Marrocos é um dos principais pontos de tentativas de entrada de imigrantes ilegais em território espanhol. Melilla é cercada por alambrados de até seis metros, em dupla linha, e onde constantemente ocorrem mortes dos dois lados; alguns casos são notificados pela imprensa internacional - quando morrem mais do que um, ou muitos. Essa situação começa a ser relatada no filme de forma muito distinta de outros documentários, com o áudio de um programa da rádio Sierra (Sitio distinto, de Mariano Ojeda), da cidade de Jaén, com dois convidados em estúdio: Mohamed Awal (originário de Gana) e José Laso (fotógrafo).

O bloco é o próprio programa de rádio na íntegra, com fotografias em estúdio e uma longa série de fotos na cidade de Melilla. Os dois convidados contam como ocorrem as imigrações africanas até esse local e como as autoridades reagem a esse intenso fluxo de pessoas que buscam melhores condições de vida na Europa através do enclave espanhol. São histórias tristes e trágicas, com fotografias que mostram o sacrifício dos africanos até chegar ao alambrado - muitos demoram meses passando por vários países para tentar entrar nessa cidade europeia, com suas muralhas. E, ao final, um depoimento de José Palazón 7 , professor e fotógrafo, vinculado a

7. Ver: http://melillafronterasur. blogspot.com/. movimentos de direitos humanos e que utiliza a fotografia como ferramenta de denúncias, até mesmo em situações forenses. Muitas fotografias aparecem com sua voz ao telefone, e podemos ver situações, relatadas pelo seu depoimento, dos africanos que vivem dentro de Melilla e dos que tentam entrar na cidade. As imagens e os relatos na voz de Palazón são muito impactantes e é efetivamente um ponto muito forte dentro da narrativa do filme quando fala de um massacre ocorrido em 2005.

No próximo bloco, dando continuidade à questão sensível da fronteira de Melilla, o diretor viaja para a cidade e encontra 
um grupo de pessoas vindo de Bangladesh, em situação crítica e vivendo miseravelmente, na ilusão de transpor as barreiras quase intransponíveis do sonho europeu. O texto é pautado no depoimento de um deles, Alom Mohamed, que conta as dificuldades de sobrevivência em seu país e para chegar até ali depois de mais de seis meses de peregrinação, e um ano e tanto em estado de espera em Melilla, deixando família com promessas de enviar dinheiro para que saiam da miséria. As fotografias mostram também o estado de pobreza por que passa esse grupo migrante, integrando fala e imagem, em carga documental. Depois do depoimento, volta a voz do diretor, agora analisando a questão, como um texto de conteúdo sociológico, e a complementaridade com as imagens da cidade, com seus símbolos hispânicos da religião, do colonizador, do soldado franquista, e também dos campos de prisioneiros imigrantes que foram flagrados, nos apresenta uma situação pouco lembrada e mostrada pelos meios de comunicação, quase esquecida (“...a los inmigrantes los cuesta llegar, mas los cuesta mas salir...”).

O bloco de Melilla encerra-se com o depoimento direto agora de José Palazón, anteriormente ouvido através do telefone do programa de rádio. Palazón localiza a questão na política europeia e na globalização, na exploração financeira e de matérias-primas, assim como nas políticas de guerra, penalizando os miseráveis que buscam somente trabalho. As imagens que acompanham o texto criam similitudes entre antigas fotografias de militares e de religiosos cristãos durante a colonização com imagens contemporâneas, colocando a questão nos mesmos parâmetros, não distinguindo as épocas. Ou seja, o relato de Palazón e as imagens localizam as multinacionais e mesmo as ONGs como causa e efeito, como a presença militar e os religiosos dos séculos anteriores, ressaltando uma superioridade dominadora. Palazón lembra que é comum que um membro da família se lance na aventura da migração para criar condições posteriores de trazer sua mulher, seus filhos, e assim ocorreu com as migrações europeias para as Américas. As significativas fotografias desse bloco são intermediadas com retratos de Palazón bebendo café e fumando, em um canto de um bar, olhando diretamente para a câmera; assim, sua análise ganha uma dimensão pessoal e intransferível de quem vive e conhece pessoas e fatos. 
O penúltimo bloco é uma narração em língua africana de um migrante dentro de um barco na escuridão. Entramos nas suas sensações e projeções de chegar a um destino pelo qual almeja. Aquarelas expressivas em animação, uma a uma, aproximam o relato em primeira pessoa das imagens, tornando realística uma situação imaginária, ou presente no imaginário da travessia, rompido com a sirene da localização: o seu sonho acabou. Ou não, pois ao final, depois dos créditos, Marko Potyomkin opta por finalizar como Lars von Trier o fez no filme Manderlay. São apresentadas fotos em sequência dos movimentos dos direitos civis nos EUA e da KKK (Ku Klux Kan). Ouvimos nesse último bloco o famoso discurso original em áudio na voz de Martin Luther King: "I have a dream...". A questão da população afrodescendente nos EUA não foi anunciada nenhuma vez no decorrer da narrativa e somente aparece nesse final, intercalando as movimentações sociais pelos direitos civis com cenas da Ku Klux Klan. A escolha do discurso do líder negro norte-americano assassinado relaciona-se com o sonho do imigrante que nos relata sua trajetória em altomar para tentar chegar à Europa, mas são situações muito distintas: o sonho individual de busca de sobrevivência e o sonho coletivo de transformações sociais. Entretanto, as imagens da década de 60 nos EUA tornaram-se ícones contemporâneos das lutas pela liberdade e pelos direitos de uma população oprimida pelo sistema segregacionista até então vigente e sustentado pelas elites brancas. A questão da migração e a situação dos imigrantes ilegais na Espanha podem ser de outra ordem, mas os sonhos, ao final, podem ser os mesmos: dignidade e cidadania.

Com 20 fotógrafos participantes e centenas de fotografias escolhidas, o filme de Marco Potyomkin é um coletivo imagético aliado a uma polifonia de vozes e músicas. Com estrutura narrativa formada por segmentos, parte de uma questão localizada na cidade de Valência para colocar em discussão o problema socioeconômico das migrações de grupos de africanos de várias nacionalidades rumo à Espanha, principalmente, em busca de sobrevivência e também de poder sonhar com seu futuro, e no imaginário eles levam o Baobab como um signo de identidade e de persistência de seus desejos. 


\section{Observações finais}

A presença da fotografia nesses três filmes referenciais da cena contemporânea espanhola traz questões diferenciadas e particularizadas em cada realização. As três produções são singulares, com diferenças conceituais no uso do fotograma fotográfico transformado em fotograma cinematográfico, ou seja, imagens fixas em movimento. Cada filme utiliza ferramentas distintas, algumas similares, para enredar e contar uma história.

Para Guerin, o esboço e o processo criativo de um futuro filme realizado através do uso intensivo do olhar fotográfico propiciam não somente a produção de um filme ficcional a partir dessas observações mas também uma montagem em blocos fragmentários explorando questões de linguagem cinematográfica. Tal experiência criativa se expande para outros desdobramentos expressivos de seu processo artístico, possibilitando múltiplos caminhos de apresentação e montagens.

Millares explora fronteiras entre o ficcional e o documentário, inventando narrativa e subjetivações a partir de fatos reais e de imagens de arquivos. Uma cerimônia festiva e oficial, elevada a uma questão conceitual no campo da arquitetura, o move para compreender um processo histórico trágico para a Espanha e para a Europa. O fotográfico aludido desde o início do filme pela escolha das fotografias enigmáticas de Atget permite que Millares procure significativos elementos ocultos de um possível crime. Millares busca o crime ficcional e passional em documentos fotográficos do evento e encontra o crime humanitário das relações ideológicas ocultas nas imagens.

Potyomkin busca em seu filme uma ação épica de luta pelas desigualdades sociais que produzem a massa de pessoas em movimentos migratórios. A partir de uma questão particular, se movimenta para o geral ao indicar que tal condição singular de imigrantes africanos em uma cidade da Espanha é somente parte de um processo exploratório muito mais amplo e complexo. O uso intenso de imagens fixas - grande parte delas, fotografias de muitos fotógrafos em distintas condições - também potencializa a dimensão mais ampla e épica da narrativa. O filme também utiliza 
o recurso fragmentário em muitos blocos para criar uma tessitura contextual das questões sociais e econômicas do processo migratório. Camadas entre som e imagem propiciam uma experiência subjetiva ao espectador, que é ativado e incentivado a associar tais planos existindo em simultaneidade.

A produção espanhola de fotofilmes analisada a partir dessas três realizações referenciais demonstra criatividade e exploração de linguagens artísticas a partir do fotográfico; elas se identificam e se coadunam na perspectiva de produções de muito baixo custo e de um trabalho mais individualizado, ou com uma equipe muito elementar, como é próprio do fotográfico. A era digital disponibiliza uma multiplicidade de ferramentas de montagem audiovisual com a imagem fixa e ao mesmo tempo possibilita que tais realizações estejam ao alcance de qualquer um; somente são necessários uma boa ideia conceitual, persistência e detalhamento do processo de montagem. Sem perspectiva comercial, tais produções marcam autorias e concepções que alimentam e expandem a cadeia experiencial iniciada por Chris Marker e indicam que o campo dos fotofilmes ainda tem muito a ser explorado. 


\section{Referências}

BORDWELL, D. "Más luz desde el este”. In: LIVRO DE TEXTOS. DVD José Luis Guerin. Barcelona: Versus, 2008. Texto traduzido e extraído do blog do autor, disponível em: <http://www. davidbordwell.net/blog/2007/1 1/05/three-nights-of-a-dreamer/>.

ESQUERRA, N. “A propósito del montaje de 'Unas fotos em la ciudad de Sylvia”. In: LIVRO DE TEXTOS. DVD José Luis Guerin. Barcelona: Versus, 2008.

FONTCUBERTA, J. "Ficciones documentales". In: FONTCUBERTA, J. La cámara de Pandora: la fotografía después de la fotografía. Barcelona: Gustavo Gili, 2010. . “La escritura de las aparências”. In: FONTCUBERTA, J. El beso de Judas: fotografía y verdad. , Barcelona: Gustavo Gili, 2009. LUCAS, G. de. Los puntos cardinales. Livro de textos. DVD José Luis Guerin. Barcelona: Versus, 2008. Texto publicado pela primeira vez em Cahiers du Cinéma España, n. 4, set. 2007.

MARÍAS, M. “Algo realmente novo: recomeçando”. Revista Contracampo, SãoPaulo,n. 90,2007.Artigopublicadooriginalmente na revista Undercurrent, edição n. 1, abr. 2006. Disponível em: < http://www.contracampo.com.br/90/artguerinmarias.htm>. Acesso em: 1 out. 2012.

. "La visión”. In: LIVRO DE TEXTOS. DVD José

Luis Guerin. Barcelona, Versus, 2008.

MILLARES, J. La imagen imaginada: notas sobre el cortometrage El pabellón Alemán. Studium 32, Campinas, 2011. Disponível em: $<$ http://www.studium.iar.unicamp.br/32/l.html>.

REVISTA CONTRACAMPO. Entrevista com José Luis Guerin. São Paulo, n. 90, 2007. Disponível em: <http://www.contracampo. com.br/90/artentrevistaguerin.htm>. Acesso em 1 out. 2012. 
TACCA, F. C. de. "Fotografia e cinema: intertextualidades". Revista Studium 27. Disponível em: <http://www.studium.iar.unicamp. br/27/03.html>. . "O fotográfico na literatura". Revista Facom (Faap), n. 23, p. 40-63, 2011. Disponível em: <http://www.faap.br/revista_ faap/revista_facom/facom_23/index.html>. 